\title{
FUNGSI PARTAI POLITIK DALAM MENINGKATKAN PARTISIPASI POLITIK DITINJAU DARI HUKUM POSITIF
}

\author{
Suimi Fales \\ Fakultas Syariah IAIN Bengkulu \\ J1. Raden Fatah Pagar Dewa Bengkulu \\ Email: Suimi@gmail.com
}

\begin{abstract}
The fact that at this time political education carried out by political parties is still very lacking. Political education is carried out only during the campaign period leading up to the election, namely voter education in terms of elections and political parties' vision and mission, this indicates that political education carried out is directed at choosing the party. The very complex relationship between social problems and political aspects makes it difficult for most citizens to understand the social dimension and the political dimension of their existence. It is also difficult to recognize political rights and their political role. The results of the study are according to Law No. 2 of 2011, that the functions of political parties are: first political education for members and the wider community to become Indonesian citizens who are aware of their rights and obligations in the life of the community, nation and state; second Creation of a climate conducive to the unity and unity of the Indonesian people for the welfare of society; thirdly Absorbers, collectors, and channelers of the people's political aspirations in formulating and determining state policies; political participation of Indonesian citizens; and fourth, political recruitment in the process of filling political positions through a democratic mechanism by paying attention to gender equality and justice.
\end{abstract}

Keywords: Political Party, Participation, Law

\begin{abstract}
Abstrak: Kenyataan yang terjadi pada saat ini pendidikan politik yang dilakukan oleh partai politik masih sangat kurang. Pendidikan politik yang dilakukan hanya pada masa kampanye menjelang pemilu, yaitu pendidikan pemilih dalam hal pemilu dan visi misi parpol, hal ini mengindikasikan bahwa pendidikan politik yang dilakukan diarahkan untuk memilih partai tersebut. Sangat rumitnya keterkaitan antara masalah kemasyarakatan dengan aspek-aspek politik membuat kebanyakan warganegara semakin sulit memahami dimensi kemasyarakatan dan dimensi politik dari eksistensi dirinya. Juga sulit mengenali hak-hak politik dan peranan politiknya. Hasil dari penelitian tersebut ialah menurut Undang-Undang Nomor 2 Tahun 2011, bahwasanya fungsi partai politik yaitu: pertama Pendidikan politik bagi anggota dan masyarakat luas agar menjadi warga negara Indonesia yang sadar akan hak dan kewajibannya dalam kehidupan bermasyarakat, berbangsa, dan bernegara; kedua Penciptaan iklim yang kondusif bagi persatuan dan kesatuan bangsa Indonesia untuk kesejahteraan masyarakat; ketiga Penyerap, penghimpun, dan penyalur aspirasi politik masyarakat dalam merumuskan dan menetapkan kebijakan negara; partisipasi politik warga negara Indonesia; dan keempat Rekrutmen politik dalam proses pengisian jabatan politik melalui mekanisme demokrasi dengan memperhatikan kesetaraan dan keadilan gender.
\end{abstract}

Kata Kunci: Partai Politik, Partisipasi, Hukum 


\section{Pendahuluan}

Partai politik adalah sebuah organisasi yang dibentuk untuk memperjuangkan suatu pandangan, keyakinan, dan cita-cita tertentu dari sejumlah orang tentang kehidupan bermasyarakat yang dilakukan dengan caracara perjuangan politik, yakni mengelola kekuasaan agar dapat mempengaruhi prosesproses pembentukan kebijakan publik. ${ }^{1}$ Partai politik merupakan instrumen yang tak terpisahkan dari sistem demokrasi di negara manapun di dunia ini. Partai politik dianggap sebagai perwujudan atau lambang negara modern. Karenanya, hampir semua negara demokrasi maupun komunis, negara maju maupun negara berkembang memiliki partai politik. Namun bentuk dan fungsi partai politik di berbagai negara berbeda satu sama lain sesuai dengan sistem politik yang diterapkan di negara itu. ${ }^{2}$

Partai politik dalam sistem politik demokrasi berfungsi sebagai pemandu berbagai kepentingan, kemudian memperjuangkan melalui proses politik dengan terlebih dahulu berupaya mencari dan mempertahankan kekuasaan melalui pemilu. ${ }^{3}$

Dalam Pasal 11 huruf a UndangUndang menyebutkan bahwa salah satu fungsi partai politik adalah sebagai sarana pendidikan politik bagi anggota dan masyarakat luas agar menjadi warga negara Indonesia yang sadar

\footnotetext{
${ }^{1}$ Efriza, Political Explore (sebuah kajian ilmu Politik), (Bandung: Alfabeta, 2012), h. 218

${ }^{2}$ Efriza, Political Explore..., h. 222

${ }^{3}$ Efriza, Political Explore..., h. 223
}

akan hak dan kewajibannya dalam kehidupan bermasyarakat, berbangsa, dan bernegara. Pendidikan politik itu sendiri menurut undangundang ini adalah proses pembelajaran dan pemahaman tentang hak, kewajiban, dan tanggung jawab setiap warga negara dalam kehidupan berbangsa dan bernegara. ${ }^{4}$ Pendidikan politik juga diartikan sebagai suatu proses mengajarkan kepada masyarakat mengenai nilai-nilai, norma-norma, serta simbol-simbol politik melalui media berupa sekolah, pemerintah, dan juga partai politik. ${ }^{5}$

Kaum politisi memahami pentingnya pendidikan politik bagi rakyat. Bahkan Plato maupun Aristoteles di zaman kuno, sampai dengan para pakar modern meyakini perlunya anggota masyarakat mendapatkan pendidikan politik, agar bisa ikut aktif berpolitik dan melakukan kegiatan-kegiatan politik melewati lembaga-lembaga politik formal. Lembaga politik dan partai-partai politik itu akan mengatur semua aspirasi politik yang ada di tengah masyarakat. ${ }^{6}$

Kenyataan yang terjadi pada saat ini pendidikan politik yang dilakukan oleh partai politik masih sangat kurang. Pendidikan politik yang dilakukan hanya pada masa kampanye menjelang pemilu, yaitu pendidikan pemilih dalam hal pemilu dan visi misi parpol,

\footnotetext{
${ }^{4}$ Undang-Undang Nomor 2 Tahun 2011
} tentang perubahan atas Undang-Undang Nomor 2 Tahun 2008 tentang Partai Politik pasal 1 angka 4.

${ }^{5}$ Muhadam Labono dan Teguh Ilham, Partai Politik dan Sistem Pemilihan Umum di Indonesia, (Jakarta: Rajawali Pers, 2017), h. 20

${ }^{6}$ Kartini Kartono, Pendidikan Politik, (Bandung: Mandar Maju, 2009), h. 55 
AL-IMARAH: Jurnal Pemerintahan dan Politik Islam Vol. 3, No. 2, 2018

hal ini mengindikasikan bahwa pendidikan politik yang dilakukan diarahkan untuk memilih partai tersebut. Kampanye politik dilakukan untuk mengikhtiarkan orang dicalonkan, dipilih, atau dipilih kembali dalam suatu jabatan resmi. Sedangkan, secara garis besar pemilih diartikan sebagai semua pihak yang menjadi tujuan utama para kontestan untuk mereka pengaruhi dan yakinkan melalui kegiatan kampanye politik agar mendukung dan kemudian memberikan suaranya kepada kontestan bersangkutan. ${ }^{7}$

Sangat rumitnya keterkaitan antara masalah kemasyarakatan dengan aspek-aspek politik membuat kebanyakan warganegara semakin sulit memahami dimensi kemasyarakatan dan dimensi politik dari eksistensi dirinya. Juga sulit mengenali hakhak politik dan peranan politiknya. Untuk itu untuk menumbuhkan daya kritis masyarakat maka diperlukanlah penguatan terhadap partai politik sehingga benar-benar mampu dalam menjalankan fungsinya dalam memberikan pendidikan politik kepada masyarakat. ${ }^{8}$

Dalam istilah Islam partai disebut hizbu, yaitu jamaah yang membentuk suatu himpunan atas dasar suatu kepentingan dan saling mendukung. ${ }^{9}$ Sedangkan fungsi partai (hizbu) di dalam Islam di antaranya, yaitu membantu seorang muslim sebagai individu

\footnotetext{
${ }^{7}$ Efriza, Political Explore..., h. 356

${ }^{8}$ Kartini Kartono, Pendidikan Politik..., h. 58

${ }^{9}$ Yahyah Ismail, Hubungan Penguasa dan Rakyat dalam Persfektif Sunnah, (Jakarta: Gema Insani Press, 1995), h. 64
}

dalam melaksanakan kewajibannya terhadap Allah, amar ma'ruf dan nahi munkar, dan untuk mewujudkan kepemimpinan bagi umat Islam di seluruh dunia. ${ }^{10}$

Menurut Ramlan Surbakti politik tidak hanya dipersepsi sebagai arena konflik dan perebutan kekuasaan, melainkan juga perumusan kebijakan dan pencapaian kepentingan umum. Di situlah, makna politik bisa bersinggungan erat dengan dakwah, dalam pengertian "upaya untuk mengembalikan manusia agar menyembah Allah semata dengan memerintahkan kema'rufan dan mencegah kemungkaran.""11 Firman Allah SWT:

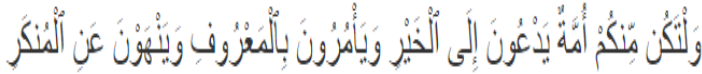

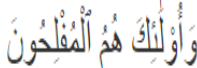

Artinya: "Dan hendaklah ada di antara kamu segolongan umat yang menyeru kepada kebajikan, menyuruh kepada yang ma'ruf dan mencegah dari yang munkar merekalah orang-orang yang beruntung."(Al-Imran: 104) ${ }^{12}$

Ayat ini menjelaskan bahwa hendaklah ada dalam kalangan di antara kalian (muslim) menyediakan diri mengadakan ajakan atau seruan, atau dakwah/mendidik, yang selalu

81

${ }^{10}$ Yahyah Ismail, Hubungan Penguasa..., h.

11 Sapto Waluyo, Kebangkitan Politik Dakwah (Konsep dan Praktik Partai Keadilan Sejahtera di Masa transisi), (Bandung: Harakatuna Publishing, 2005), h. 31

${ }^{12}$ Departemen Agama RI, Al-Qur'an dan Terjemahnya, (Bandung :Cv Diponegoro, 2010), h. 63 
membawa dan mengajak manusia untuk berbuat kebajikan, menyuruh berbuat ma'ruf, yaitu yang patut, pantas dan sopan dan mencegah, melarang perbuatan munkar, yang di benci dan yang tidak diterima. ${ }^{13}$

Dari sini terlihat jelas bahwa, salah satu fungsi dari partai politik dalam pendidikan harus ada seorang pendidik yang senantiasa memberikan petunjuk, membimbing mengarahkan, mengajak dan mendidik manusia ke dalam kebaikan. Dan bahkan seorang pendidik mempunyai kewajiban untuk amar ma'ruf dan nahi munkar, yang menjadi pokok penting dari pokok-pokok agama. $^{14}$ Pendidikan politik menjadi modal utama ketahanan umat, dakwah harus tetap berjalan, di bawah tekanan maupun di tengah godan harta dan kekuasaan.

\section{Pembahasan}

\section{Pengertian Partai Politik}

Secara etimologis Maurice Duverger menyebutkan bahwa kata partai berasal dari bahasa Latin pars yang bererarti "bagian". Selanjutnya Jimly Asshiddiqie menyebutkan bahwa partai juga berasal dari bahasa Inggris part, yang berarti bagian atau golongan. Sedangkan politik secara etimologis berasal dari bahasa Yunani, yaitu polis yang berarti kota atau komunitas secara keseluruhan. Selanjutnya menurut

13 Abdulmalik Abdulkarim Amrullah (Hamka), Tafsir al-Qur'an, (Jakarta: Yayasan Nurul Islam, 1981), h. 40

${ }^{14}$ Hasbi ash-Shiddieqy, Tafsir al-Bayyan, Jil. 1, (Jakarta: al-Ma'arif, 1977), h. 311
Inu Kencana Syafii dari segi etimologis, kata politik merupakan terjemah bahasa Arab dari kata siyasyah yang kemudian diterjemahkan menjadi siasat, atau dalam bahasa Inggrisnya disebut politics. Menurut Kamus Lengkap Bahasa Indonesia, siasat itu sendiri berarti muslihat, taktik, tindakan yang licin, akal, kebijakan. Berdasarkan pengertian tersebut maka politik merupakan cara yang dipilih untuk mencapai suatu tujuan. $^{15}$

Secara umum partai politik adalah suatu kelompok terorganisir yang anggotaanggotanya mempunyai orientasi, nilai-nilai dan cita-cita yang sama. Tujuan kelompok ini ialah untuk memperoleh kekuasaan politik dan merebut kedudukan politik biasanya dengan cara konstitusional untuk melaksanakan programnya. ${ }^{16}$

Menurut para ahli definisi partai politik menurut para ahli:

a. Edmund Burk

Partai politik adalah kumpulan orang-orang yang bertujuan untuk mempromosikan dengan usaha bersama, kepentingan nasional berdasarkan beberapa prinsip khusus yang telah mereka setujui bersama. ${ }^{17}$

15 Muhadam Labono dan Teguh Ilham, Partai Politik dan Sistem Pemilihan Umum di Indonesia, (Jakarta: Rajawali Pers, 2017), h. 9

16 Miriam Budiardjo, Dasar-dasar Ilmu Politik, (Jakarta: PT Gramedia Pustaka Utama, 2008), h. 404

17 Ahmad Farhan Hamid, Partai Politik Lokal di Aceh (Desentralisasi Politik dalam Negara Kebangsaan), (Jakarta: Kemitraan, 2008), h. 5 
b. Roy C. Macridis

Partai politik adalah asosiasi yang mengaktifkan, memobilisasi rakyat, dan mewakili kepentingan tertentu, memberikan jalan kompromi bagi pendapat-pendapat yang bersaing, dan memunculkan kepemimpinan politik, serta digunakan sebagai alat untuk memperoleh kekuasaan dan untuk memerintah.

c. Carl J. Friedrich

Partai politik adalah sekelompok manusia yang terorganisir secara stabil dengan tujuan merebut atau mempertahankan penguasaan terhadap pemerintah bagi pimpinan partainya dan berdasarkan penguasaan ini, memberikan kepada anggota partainya kemanfaatan yang bersifat adil dan materiil.

d. Sigmund Neumann

$$
\text { Partai politik adalah }
$$
organisasi dari aktivis-aktivis politik yang berusaha untuk menguasai kekuasaan pemerintahan serta merebut dukungan rakyat melalui persaingan dengan suatu golongan atau golongan-golongan lain yang mempunyai pandangan yang berbeda.

\section{e. Giovanni Sartori}

$$
\text { Partai politik adalah }
$$
sekelompok politik yang mengikuti pemilihan umum dan melalui pemilihan umum itu, mampu menempatkan calon-calonnya untuk menduduki jabatan-jabatan publik.

f. David E. Apter

Partai politik adalah perantara tunggal terpenting untuk politik, daya saing, tawar-menawar, dan negosiasi. Partai memungkinkan para politisi tetap dekat dengan publik di satu pihak dan menjadi sesuatu yang berlainan bagi sejumlah besar orang. Sebaliknya, ketika memperoleh jabatan, para politisi dihadapkan mampu berdiri di atas berbagai kepentingan publik yang lebih umum. ${ }^{18}$

g. Surbakti

Partai politik adalah anggota yang terorganisasi secara rapi dan stabil yang dipersatukan dan dimotivasi dengan idiologi tertentu, dan yang berusaha mencari dam mempertahankan kekuasaan dalam pemerintahan melalui pemilu guna melaksaanakan alternatif kebijakan umum yang mereka susun. ${ }^{19}$

h. R.H. Soltau

Partai politik adalah sekelompok warga kurang lebih terorganisir, yang bertindak
${ }^{18}$ Efriza, Political Explore (sebuah kajian ilmu Politik), (Bandung: Alfabeta, 2012), h. 214

${ }^{19}$ Efriza, Political Explore..., h. 217 
Suimi Fales :

Fungsi Partai Politik Dalam Meningkatkan Partisipasi Politik Ditinjau Dari Hukum Positif

sebagai unit politik dengan menggunakan hak suara mereka, bertujuan untuk mengontrol pemerintah dan untuk melaksanakan kebijakan umum mereka.

\section{Sejarah Perkembangan Partai Politik} di Indonesia

a. Partai Politik Pada Masa Demokrasi Terpimpin (Orde Lama)

Pada masa pemerintahan presiden Soekarno dikenal dengan dua sistem pemerintahan, yaitu sistem Parlementer yang biasa dikenal juga dengan masa Demokrasi Liberal dan sistem Presidensial atau dikenal juga dengan masa Demokrasi Terpimpin atau sering disebut sebagai masa Orde Lama. $^{20}$

Pertama, masa Demokrasi Liberal. Pada masa ini Indonesia (1950-1959) menganut sistem pemerintahan Parlementer, pada masa ini jumlah partai politik cukup banyak. $^{21}$ Pada masa ini Indonesia menganut sistem multipartai, secara keseluruhan jumlah partai yang ada sebanyak 29 partai politik.

\section{Partai Politik..., h. 88}

20 Muhadam Labono dan Teguh Ilham,

${ }^{21}$ Digunakan sistem kepartaian multipartai saat itu berawal dari Maklumat Pemerintah No. X tanggal 14 Oktober 1945. Kala itu pemerintah membuka kesempatan seluas-luasnya bagi warga negara untuk mendirikan partai agar bisa ikut serta dalam pemilu yang akan dilaksanakan selanjutnya.
Kemajemukan masyarakat Indonesia merupakan faktor yang sangat mempengaruhi lahirnya partaipartai politik dan mendorong terbentuknya sistem multipartai di Indonesia. Lahirnya partai tersebut, baik sebelum ataupun sesudah kemerdekaan, tidak terlepas dari ikatan-ikatan kelompok yang kuat, termasuk dalam ikatan idiologi.

Herbert Feith membagi corak aliran patai-partai pada 1950-an ke dalam lima aliran besar, yaitu Nasionalisme Radikal, Tradisionalisme Jawa, Islam, Sosialisme, Demokratis, dan Komunisme. ${ }^{22}$ Berbeda dengan pola klasifikasi Herbert Feith, pemerintah melalui kementerian penerangan menerbitkan buku kepartaian Indonesia yang membagi partai-partai yang terdapat pada masa tersebut ke dalam empat klasifikasi, yaitu dasar ketuhanan, dasar kebangsaan, dasar marxisme, partai lain-lain.

Pada tahun 1952 terdapat dua partai baru yang berdiri secara resmi namun belum sempat dimasukkan ke dalam daftar tersebut, yaitu Nahdlatul Ulama (NU) dan Ikatan Pendukung Kemerdekaan Indonesia (IPKI).

22 Muhadam Labono dan Teguh Ilham, Partai Politik..., h. 89 
Berdasarkan kasifikasi tersebut dapat disimpulkan bahwa terdapat empat ideologi yang melandasi terbentuknya partai di Indonesia, yaitu: agama, nasionalis, sosialis dan komunis.

Kedua, masa Demokrasi Terpimpin. Masa Demokrasi Terpimpin atau Orde Lama berlangsung mulai tahun 1959 sampai dengan 1965. Miriam Budiardjo membagi sejarah perkembangan demokrasi Indonesia menjadi tiga bagian dan menetapkan tahun 19591965 sebagai masa Demokrasi Terpimpin yang ditandai dengan dominasi presiden, terbatasnya peranan partai politik, berkembangnya pengaruh komunis, serta meluasnya peranan ABRI sebagai unsur politik. ${ }^{23}$

Sejak berlangsungnya masa Orde Lama atau Demokrasi Terpimpin kekuasaan berpusat pada tiga kekuatan, yaitu presiden, PKI, dan TNI AD. Partai politik tidak memiliki peranan yang begitu penting.

b. Partai Politik Pada Masa Orde Baru

Sejak peristiwa G $30 \mathrm{~S}$ PKI pada tahun 1965 Indonesia mengalami pergolakan yang tercatat dalam sejarah. Setelah jatuhnya dua kekuatan yang mendominasi selama masa Orde Lama, yaitu presiden dan PKI, tinggal satu kekuatan lagi yang tersisa, yaitu TNI AD. Berdasarkan surat Perintah 11 Maret 1967 atau lebih dikenal dengan SUPERSEMAR, tongkat kekuasaan presiden diberikan kepada jenderal TNI AD bernama Soeharto. Bersamaan dengan diangkatnya Soeharto sebagai presiden, masa Orde Baru pun dimulai. Setelah diangkat sebagai presiden pada tahun 1967 dan pada tahun 1968 Presiden Soeharto menjalankan pemerintahan. Demikian pergeseran kekuasaan dari politisi sipil ke militer terjadi yang menjadi ciri khas masa Orde Baru.

Salah satu perubahan dalam tubuh partai yang dilakukan pertama kali adalah dirombaknya tokoh partai PNI, yaitu dengan menyisihkan tokoh partai yang tergolong radikal dan condong ke sayap kiri dengan tokoh sayap kanan yang moderat dan dekat dengan penguasa. Selain itu muncul pula partai baru, yaitu Partai Muslim di Indonesia atau Permusi yang merupakan partai penampung aspirasi politik umat Islam yang tidak tergolong ke dalam tiga partai politik Islam lainnya yang telah ada. 
Suimi Fales :

Fungsi Partai Politik Dalam Meningkatkan Partisipasi Politik Ditinjau Dari Hukum Positif

Pada tahun 1973 terjadi peleburan partai politik atau fusi. Melalui Undang-Undang Nomor 3 Tahun 1973 pemerintah menyederhanakan jumlah partai dengan kebijakan fusi partai. Empat partai politik Islam yaitu NU, Parmusi, Partai Sarikat Islam, dan Perti bergabung menjadi Partai Persatuan Pembangunan (PPP). Lima partai lainnya yaitu PNI, Partai Kristen Indonesia, Partai Katholik, Partai Murba, dan IPKI bergabung menjadi Partai Demokrasi Indonesia. Sehingga pada tahun 1977 hanya ada tiga organisasi politik yaitu PPP, PDI, dan GOLKAR.

c. Partai Politik Pada Masa Orde Reformasi

Era Reformasi yang muncul setelah runtuhnya rezim Orde Baru merupakan era yang menjanjikan harapan baru dalam kehidupan berbangsa dan bernegara yang lebih baik. Setelah mengalami pengkerdilan partai pada masa Orde Baru, partai politik kembali bergeliat pada era Reformasi yang membawa angin segar.

Runtuhnya pemerintahan Soeharto mengubah tatanan politik di Indonesia, termasuk di dalamnya sistem kepartaian. Jika pada masa Orde Baru Indonesia dikuasai oleh pemerintahan yang otoritarian dengan sistem partai tunggal, maka pada era Reformasi demokrasi langsunglah yang berkuasa. Akhirnya, setiap individu di Indonesia memiliki hak yang sama untuk mengeluarkan pendapat, berserikat, dan berekspresi. Euforia politik ditandai dengan kemunculan begitu banyak partai politik.

Kemunculan banyak parpol pada era Reformasi ini ditandai dengan dikeluarkannya kebijakan pemerintah interregnum B.J. Habibie untuk menerapkan kembali sistem multipartai. Jika pada masa Orde Baru hanya terdapat dua partai dan satu golongan karya, pada tahun 1999 tercatat ada 141 partai politik.

Walaupun pada era Reformasi ini, Indonesia kembali mengulang sejarah diberlakukannya sistem kepartaian mutipartai seperti yang pernah dipraktikkan pada masa Demokrasi Liberal dan terpimpin. Akan tetapi terdapat suatu perbedaan yang mendasar antara kedua masa tersebut. Ketika pada masa Demokrasi Liberal atau Terpimpin partai-partai mempunyai ideologi yang jelas dan dijalankan secara konsisten, namun pada era Reformasi ideologi partai kurang berpengaruh dan terkadang hanyalah dijadikan 
AL-IMARAH: Jurnal Pemerintahan dan Politik Islam Vol. 3, No. 2, 2018

sebagai pajangan pada AD/ART partai saja.

\section{Fungsi Partai Politik}

Menurut Pasal 11 UndangUndang Nomor 2 Tahun 2011 tentang perubahan atas Undang-Undang Nomor 2 Tahun 2008 tentang Partai Politik disebutkan fungsi partai politik adalah sebagai berikut:

a. Pendidikan politik bagi anggota dan masyarakat luas agar menjadi warga negara Indonesia yang sadar akan hak dan kewajibannya dalam kehidupan bermasyarakat, berbangsa, dan bernegara;

b. Penciptaan iklim yang kondusif bagi persatuan dan kesatuan bangsa Indonesia untuk kesejahteraan masyarakat;

c. Penyerap, penghimpun, dan penyalur aspirasi politik masyarakat dalam merumuskan dan menetapkan kebijakan negara; partisipasi politik warga negara Indonesia; dan

d. Rekrutmen politik dalam proses pengisian jabatan politik melalui mekanisme demokrasi dengan memperhatikan kesetaraan dan keadilan gender. ${ }^{24}$

Dalam negara demokrasi partai politik menyelenggarakan beberapa fungsi, yaitu sebagai berikut:

a. Sebagai Sarana Komunikasi Politik Dalam hal ini partai politik berfungsi menyatukan aspirasi di dalam masyarakat yang sangat luas dan kompleks kemudian partai politik mengagresasi dan mengartikulasi aspirasi tersebut agar tidak terjadi simpang siur dan saling berbenturan. Setelah itu partai politik merumuskannya menjadi usul kebijakan. Usul kebijakan ini dimasukkan ke dalam program atau platform partai (goal formulation) untuk diperjuangkan atau disampaikan melalui parlemen kepada pemerintah agar dijadikan kebijakan umum (public policy).

Partai politik juga berfungsi memperbincangkan dan menyebarluaskan rencana-rencana dan kebijakan-kebijakan pemerintah. Dengan demikian terjadi arus informasi dan dialog dua arah. Dari atas ke bawah dan dari bawah ke atas. Dalam pada itu partai politik memainkan peran 
Suimi Fales : Fungsi Partai Politik Dalam Meningkatkan Partisipasi Politik Ditinjau Dari Hukum Positif

sebagai penghubung antara yang memerintah dan yang diperintah. ${ }^{25}$

b. Sebagai Sarana Sosialisasi Politik

$$
\text { Dalam ilmu politik }
$$

sosialisasi diartikan sebagai suatu proses yang melaluinya seseorang memperoleh sikap dan orientasi terhadap fenomena politik, yang umumnya berlaku dalam masyarakat di mana ia berada. Ia adalah bagian dari proses yang menentukan sikap politik seseorang.

Sosialisasi politik juga adalah sebagai proses yang melaluinya masyarakat menyampaikan norma-norma dan nilai-nilai dari satu generasi ke generasi berikutnya. Di sisi lain fungsi sosialisasi partai adalah upaya menciptakan citra (image) bahwa ia memperjuangkan kepentingan umum. Selain itu ada lagi fungsi partai politik yang lebih tinggi nilainya apabila partai politik dapat menjalankannya, yaitu mendidik anggota-anggotanya menjadi manusia yang sadar akan tanggungjawabnya sebagai warga negara dan menempatkan kepentingan sendiri di bawah kepentingan nasional.

25 Miriam Budiardjo, Dasar-dasar..., h c. Sebagai Sarana Rekrutmen Politik Fungsi ini berkaitan erat dengan masalah seleksi kepemimpinan, baik kepemimpinan internal maupun kepemimpinan nasional yang lebih luas. Untuk kepentingan internalnya, setiap partai butuh kader-kader yang berkualitas, karena hanya dengan kader yang demikian ia dapat menjadi partai yang mempunyai kesempatan lebih besar untuk mengembangkan diri. Dengan mempunyai kader-kader yang baik, partai politik tidak akan sulit menentukan pemimpinnya sendiri dan mempunyai peluang untuk mengajukan calon untuk masuk ke bursa kepemimpinan nasional.

Selain untuk tingkatan seperti itu partai politik juga berkepentingan memperluas atau memperbanyak keanggotaanya. Maka ia pun berusaha menarik sebanyak-banyaknya orang untuk menjadi anggotanya. Dengan didirikannya organisasi-organisasi massa (sebagai onderbouw) yang melibatkan golongan-golongan buruh, petani, pemuda, mahasiswa, wanita dan sebagainya, kesempatan untuk berpartisipasi diperluas.

d. Sebagai Sarana Pengatur Konflik 
Partai politik berfungsi menjadi penghubung psikologis dan organisasional antara warga negara dengan pemerintahnya. Selain itu partai melakukan konsolidasi dan artikulasi tuntutantuntutan yang beragam yang berkembang di berbagai kelompok masyarakat. Partai juga merekrut orang-orang untuk diikutsertakan dalam kontes pemilihan wakilwakil rakyat dan menemukan orang-orang yang cakap untuk menduduki posisi-posisi eksekutif.

\section{Penutup}

1. Pengertian Partai politik baik secara etimology/bahasa ataupun menurut para ahli bahwasanya politik adalah suatu kelompok terorganisir yang anggotaanggotanya mempunyai orientasi, nilai-nilai dan cita-cita yang sama. Tujuan kelompok ini ialah untuk memperoleh kekuasaan politik dan merebut kedudukan politik biasanya dengan cara konstitusional untuk melaksanakan programnya.

2. Indonesia kembali mengulang sejarah diberlakukannya sistem kepartaian mutipartai seperti yang pernah dipraktikkan pada masa Demokrasi Liberal dan terpimpin pada era orde lama dan era orde baru. Akan tetapi terdapat suatu perbedaan yang mendasar antara kedua masa tersebut. Ketika pada masa Demokrasi Liberal atau Terpimpin partai-partai mempunyai ideologi yang jelas dan dijalankan secara konsisten, namun pada era Reformasi ideologi partai kurang berpengaruh dan terkadang hanyalah dijadikan sebagai pajangan pada $\mathrm{AD} / \mathrm{ART}$ partai saja.

3. Menurut Undang-Undang Nomor 2 Tahun 2011, bahwasanya fungsi partai politik yaitu: pertama Pendidikan politik bagi anggota dan masyarakat luas agar menjadi warga negara Indonesia yang sadar akan hak dan kewajibannya dalam kehidupan bermasyarakat, berbangsa, dan bernegara; kedua Penciptaan iklim yang kondusif bagi persatuan dan kesatuan bangsa Indonesia untuk kesejahteraan masyarakat; ketiga Penyerap, penghimpun, dan penyalur aspirasi politik masyarakat dalam merumuskan dan menetapkan kebijakan negara; partisipasi politik warga negara Indonesia; dan keempat Rekrutmen politik dalam proses pengisian jabatan politik melalui mekanisme demokrasi dengan memperhatikan kesetaraan dan keadilan gender.

\section{Pustaka Acuan}

Abdulmalik Abdulkarim Amrullah (Hamka), Tafsir al-Qur'an, (Jakarta: Yayasan Nurul Islam, 1981)

Departemen Agama RI, Al-Qur'an dan Terjemahnya, (Bandung: $\quad \mathrm{Cv}$ Diponegoro, 2010)

Efriza, Political Explore (sebuah kajian ilmu Politik), (Bandung: Alfabeta, 2012) 
Kartini Kartono, Pendidikan Politik,

(Bandung: Mandar Maju, 2009)

Hasbi ash-Shiddieqy, Tafsir al-Bayyan, Jil. 1, (Jakarta: al-Ma'arif, 1977)

Muhadam Labono dan Teguh Ilham, Partai Politik dan Sistem Pemilihan Umum di Indonesia, (Jakarta: Rajawali Pers, 2017)

Sapto Waluyo, Kebangkitan Politik Dakwah (Konsep dan Praktik Partai Keadilan Sejahtera di Masa transisi), (Bandung: Harakatuna Publishing, 2005)

Undang-Undang Nomor 2 Tahun 2011 tentang perubahan atas Undang-Undang Nomor 2 Tahun 2008 tentang Partai Politik.

Yahyah Ismail, Hubungan Penguasa dan Rakyat dalam Persfektif Sunnah, (Jakarta: Gema Insani Press, 1995)

Miriam Budiardjo, Dasar-dasar Ilmu Politik, (Jakarta: PT Gramedia Pustaka Utama, 2008) 